\title{
PALAEOHISTORIA
}

ACTA ET COMMUNICATIONES

INSTITUTI ARCHAEOLOGICI

UNIVERSITATIS GRONINGANAE

\author{
$61 / 62$ \\ (2019/2020)
}

University of Groningen / Groningen Institute of Archaeology

\&

Barkhuis

Groningen 2021 


\section{Editorial staff}

P.A.J. Attema, E. Bolhuis, R.T.J. Cappers, P.D. Jordan, F. Kramer (Editorial Coordinator), M.A. Los-Weijns, S. Needs-Howarth (Copy Editor), D.C.M. Raemaekers, S. Voutsaki

\section{Drawing office}

S.E. Boersma, E. Bolhuis (Coordinator), M.A. Los-Weijns, S. Tiebackx

\section{Address}

University of Groningen

Groningen Institute of Archaeology

Poststraat 6

9712 ER Groningen

The Netherlands

gia@rug.nl

Website

www.palaeohistoria.nl

DOI: https://doi.org/10.21827/5beaafbcc2bf2

Publisher's address

Barkhuis

Kooiweg 38

9761 GL Eelde

The Netherlands

info@barkhuis.nl

www.barkhuis.nl

Typesetting

Hannie Steegstra

Cover design

S.E. Boersma

Cover

A decorated Late Postclassic Mixtec human skull from Teotitlán del Camino, Oaxaca, Mexico, possibly dating to c.1400-1520 CE. The type of adhesive used to affix the mosaic to the skull raised some doubts about the authenticity of the object. Photo P. Erdil. (Collection Nationaal Museum van Wereldculturen. Coll.No. RV-4007-1.)

Copyright @ 2021 Groningen Institute of Archaeology, University of Groningen, the Netherlands.

All rights reserved. No part of this publication or the information contained herein may be reproduced, stored in a retrieval system, or transmitted in any form or by any means, electronical, mechanical, by photocopying, recording or otherwise, without prior written permission from the Groningen Institute of Archaeology, University of Groningen.

Although all care is taken to ensure the integrity and quality of this publication and the information herein, no reponsibility is assumed by the publishers nor the authors for any damage to property or persons as a result of operation or use of this publication and/or the information contained herein. 


\section{Contents}

In memoriam Piet Kooi

W.A.B. van der Sanden

Bibliography of Piet Kooi

Kirsten van der Ploeg.

In memoriam Harm Tjalling Waterbolk

Archaeologist with a passion for nature and landscape

J. Bazelmans \& J. Kolen

Bibliography of H.T. Waterbolk. 16

Super interesting black hole?

The micromorphology of organic materials in a Mesolithic hearth pit feature from the site of Soest-Staringlaan (the Netherlands)

D.J. Huisman \& L.A. Tebbens

Fossilized fashion and social sparkle

Dutch Bronze Age bracelets in context

S. Arnoldussen \& H. Steegstra

A pilot study on coarse ware ceramic fabrics from the Ayios Vasileios Survey Project

(Greece)

G.J.M. van Oortmerssen \& C.W. Wiersma

Tracing the Final Bronze Age-Early Iron Age transition

Groningen Institute of Archaeology settlement excavations in the Sibaritide, 2018-2019

P.M. van Leusen \& F. Ippolito

Grave goods from Sveta Lucija (Slovenia) in Groningen (the Netherlands)

Contextualising old study collections

Albert J. Nijboer

Terra sigillata in southern Latium

The evidence from the Pontine Region Project, 1987-2014

G.W. Tol, T.C.A. de Haas \& P.A.J. Attema

Isolated and backward Westerwolde (Groningen, the Netherlands)?

A confrontation of archaeological and historical data from the Middle Ages

in a wider geographical context

Henny A. Groenendijk \& Remi van Schaïk

Radiocarbon-based investigations into the authenticity of Mesoamerican artefacts in museum contexts

P. Erdil, M. Kuitems, M. Berger \& M.W. Dee 



\title{
Super interesting black hole?
}

\section{The micromorphology of organic materials in a Mesolithic hearth pit feature from the site of Soest-Staringlaan (the Netherlands)}

\author{
D.J. Huisman ${ }^{a, b}$ \& L.A. Tebbens ${ }^{c}$ \\ a Rijksdienst voor het Cultureel Erfgoed. Corresponding author \\ b Groningen Institute of Archaeology, University of Groningen, hans.huisman@rug.nl \\ c BAAC Archaeological Consultancy
}

\begin{abstract}
A series of thin sections from a Mesolithic hearth pit from the site of Soest-Staringlaan (the Netherlands) were studied to assess the variability of the charred and non-charred organic remains inside them. Non-charred remains included plant roots; fungal fruiting bodies and hyphae; mesofauna coprolites; and podzolization-related polymorphic humus and monomorphic humus coatings. Charred remains included charcoal of coniferous wood, charred non-woody plant material and fragments of wood. However, a large proportion of the charred material consists of fine, powdery fragments. This may at least partly be due to trampling and/or eluviation of disintegrating charcoal.

Most of the micromorphological features in the Soest pit are similar to those found in pits from previously investigated Mesolithic sites. Common features include the presence of large fragments of charcoal in the lower parts of hearth pits, tar, charred humus and evidence for charcoal disintegration and eluviation.

The combined results first and foremost demonstrate the strong variability between samples within the same feature. This implies that multiple samples from a pit are necessary in order to at least attempt to try to capture this variability. It is also clear from the results that sampling should include layers or deposits that macroscopically seem to be outside the feature proper. These may contain parts of the phenomenon studied that are difficult to recognize with the naked eye.

These observations add to the notion that Mesolithic hearth pits are generally formed by the same human activities, formation processes and taphonomy. However, they make clear that intense sampling is needed for any research to better understand the formation of these pits and that supplemental chemical analyses may be needed to better interpret the observed features and get a better idea of the potential use of these common Mesolithic features.
\end{abstract}

Keywords: the Netherlands, Mesolithic, micromorphology, hearth pit.

\section{Introduction}

Hearth pits regularly occur in Mesolithic contexts in the Netherlands and adjacent parts of Belgium and Germany (> 100 archaeological sites). They typically consist of a U-shaped pit feature some $60-110 \mathrm{~cm}$ wide and $50-90 \mathrm{~cm}$ deep (Peeters \& Niekus 2017), dug into Pleistocene aeolian coversand. They contain black, charcoal-bearing sand and they frequently contain larger chunks of charcoal, especially in the lower fill, whereas artefacts or other types of charred remains are scarce. Especially north of the Rhine, they can occur as single features or in pairs or triplets, and several excavations have revealed clusters of dozens to hundreds of such features (e.g. Peeters \& Niekus 2017).

Recently, Achard-Corompt et al. (2017) reported similar features from France. Although fire-related features are known from Mesolithic contexts in e.g. Scandinavia and the British Isles, these have much more variable morphologies, and in general do not have the U-shaped morphology that we see in the Netherlands and neighbouring countries (e.g. Boyd \& Kenworthy 1991; Blinkhorn et al. 2017; Kubiak-Martens 2002). Unless they are postholes, these features are usually interpreted as cooking pits or hearths, as are, for example, Mesolithic surface hearths found in the Netherlands (Peeters \& 
Hoogestijn 2001) and - more generally - combustion features from a range of Palaeolithic and Mesolithic contexts (see Mallol et al. 2017 for a recent overview).

Typical Mesolithic hearth pits from the Low Countries have been interpreted on various occasions as having some function in food preparation (cooking, roasting, smoking; e.g. Groenendijk 1987). More recently, several publications have proposed that these pits could have been used for the production of wood tar (see Peeters et al. 2017 for an overview). It is also important to keep in mind that different pits may have been used for a range of activities. The theory that the pits would be the result of the burning down of ants' nests during forest fires (Crombé et al. 2015; Crombé \& Langohr 2020) has recently been discussed and rejected by Huisman $e t$ al. (2020).

Previous specialist research included charcoal studies, archaeobotanical research, chemical analyses and soil micromorphological studies. However, after decades of research and discussions, there is still no consensus on the reason why the pits were dug and what post-depositional processes may be involved after the filling in of the pits. In the present publication, we want to add to the corpus of existing micromorphological data on Mesolithic hearth pits in order to contribute to the overall discussion on hearth pit formation and use (cf. Peeters \& Niekus 2017). Until now, research into the formation and use of these pits has in most cases been hampered because during excavation, a pit is often only discovered after removal of the upper soil profile. As a consequence, only the lower part of the pit is investigated. In most cases, the top $c .50 \mathrm{~cm}$ is removed with the overburden, because this top part is difficult to distinguish from the prevalent and strongly coloured podzol B-horizons. Only when the excavation reaches the BCor C-horizons is the pit recognized. Commonly, micromorphological sampling and research on these features is therefore by necessity restricted to this lower fill. Huisman et al. (2019) were the first to sample a complete profile through a hearth pit, from the top of the soil profile to the C-horizon below the pit, as well as the adjacent 'natural' soil profile, for micromorphological research.

A study comparing micromorphological thin sections from hearth pits from three different sites by Kamstra (2019) identified several common features. The lower fill of such pits contains charcoal fragments and fragments of wood tar, which indicate that oxygen-starved fires were involved in their formation. They also contain charred soil organic matter, including charred polymorphic humus, monomorphic humus coatings and fungal fruiting bodies (sclerotia). The upper fill, however, contains considerable amounts of polymorphic humus, interpreted as decayed litter remains (see also Huisman et al. 2019). Moreover, there were indications for post-depositional degradation of charcoal and eluviation of charcoal and clay to pristine deposits underneath the pits due to the effects of (alkaline) ashes in the pit (Huisman et al. 2019; see Slager \& van de Wetering 1977; Huisman et al. 2012 for the relation among ash-induced alkalinity, charcoal degradation and clay eluviation).

The available micromorphological data derive mainly from single samples or from single profiles that cross-section (part of) a pit feature. A big unknown variable in this is how representative such samples or profiles are for the entire pit or, indeed, for the various macroscopically discernible layers within the pit. In the present publication, we discuss data from Mesolithic hearth pit HAK-019 in Soest that was specifically sampled to investigate the micromorphological variability of the pit and the surrounding soil layers and to determine the representativity of single samples. A better knowledge of this variability may help in designing sample protocols for future research into the formation and use of these pits. As the key to the potential use of these pits lies in the organic content (charred or noncharred), we focus our study on these components.

\section{Site characteristics}

The sampled hearth pit HAK-019 is part of an excavation measuring $6440 \mathrm{~m}^{2}$ in the south-eastern part of the village of Soest (Fig. 1), in the province of Utrecht, in the central Netherlands. The site is named after the modern-day street where it was found, the Staringlaan. The site is located on coversand deposits, at an elevation at around $4 \mathrm{~m}$ above Dutch ordnance level. Soest lies north-east of the ice-pushed ridge known as the Utrechtse Heuvelrug and borders the Saalian glacier tongue basin known as the Gelderse Vallei. North-east of this ridge, the smaller Soest 'pushed ridge' can be recognized as a convex landscape feature. The palaeotopography dips slightly in a north-easterly direction and gives way some $2 \mathrm{~km}$ farther along to the palaeovalley of the Eem River, which drains the central part of the Gelderse Vallei. To the north, north-east and southeast of this ridge are slightly undulating coversands that were deposited on the lee side of the ice-pushed ridges. The coversands include the so-called Younger Coversand I and Younger Coversand II, separated by the Usselo Interstadial soil (see Fig. 2). The Usselo soil is developed as a grey, loamy layer, with characteristic charcoal fragments and $2 \mathrm{~cm}$ wide dung beetle burrows in its upper portion and dates to the late Allerød-early Younger Dryas. Five optically stimulated luminescence (OSL) dates and one ${ }^{14} \mathrm{C}$-date (on Pinus charcoal from the Usselo soil; GrA-69482) date the Younger Coversand I at 12700 and $10850 \mathrm{cal}$. yr. BCE, the Usselo soil at 10 850-10 $725 \mathrm{cal}$. yr. BCE and the Younger Coversand II at $10725-9400$ cal yr. BCE (Tebbens 2019).

A Holocene podzol developed in the Younger Coversand II: a hydropodzol in the lower-lying, 
Fig. 1. Regional and local elevation maps showing the location of the research site in red (graphic BAAC and H. Huisman).

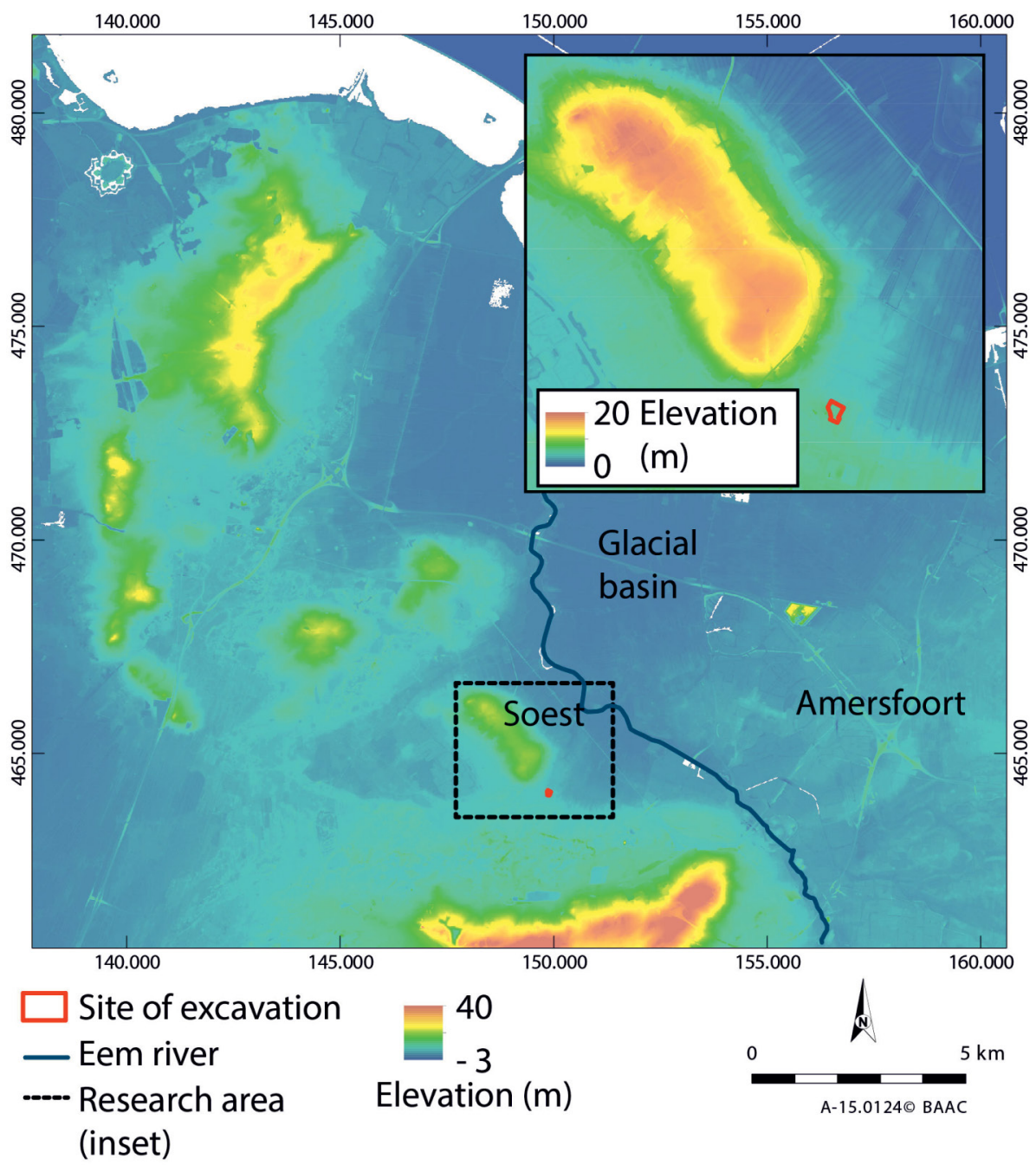

that hardly any later Mesolithic features were encountered: Out of a wide range of 73 dated features and flint scatters, only one hearth pit (HAK-016, the youngest feature at the site) was ${ }^{14} \mathrm{C}$-dated to the late Mesolithic (7235 \pm 36 BP [RICH-24929], or 6210-6020 cal. yr. BCE). Even younger features and finds were absent. A similar phenomenon was seen at the site of Utrecht-Hoofddijk, some $20 \mathrm{~km}$ south-west of Soest. From a total of 51 ${ }^{14} \mathrm{C}$-dated features, the youngest feature dated from $7300 \pm 50$ BP, or 6326-6051 cal. yr. BCE (Dielemans 2018, 35). At Soest, nearly all early and middle Mesolithic features were well preserved, because they were covered by a 5-10 cm thick peat layer. This peat layer was only absent in the slightly elevated, south-western part of the excavation.

\section{The sampled feature}

The location of the pit sampled for this research (HAK019; see Fig. 3) was known beforehand because the pit had been recognized in the side wall profile of a test trench (Stolk et al. 2015). Because of this, the hearth pit could be sampled from the very top of the original podzol profile down to its base during the excavation. The 


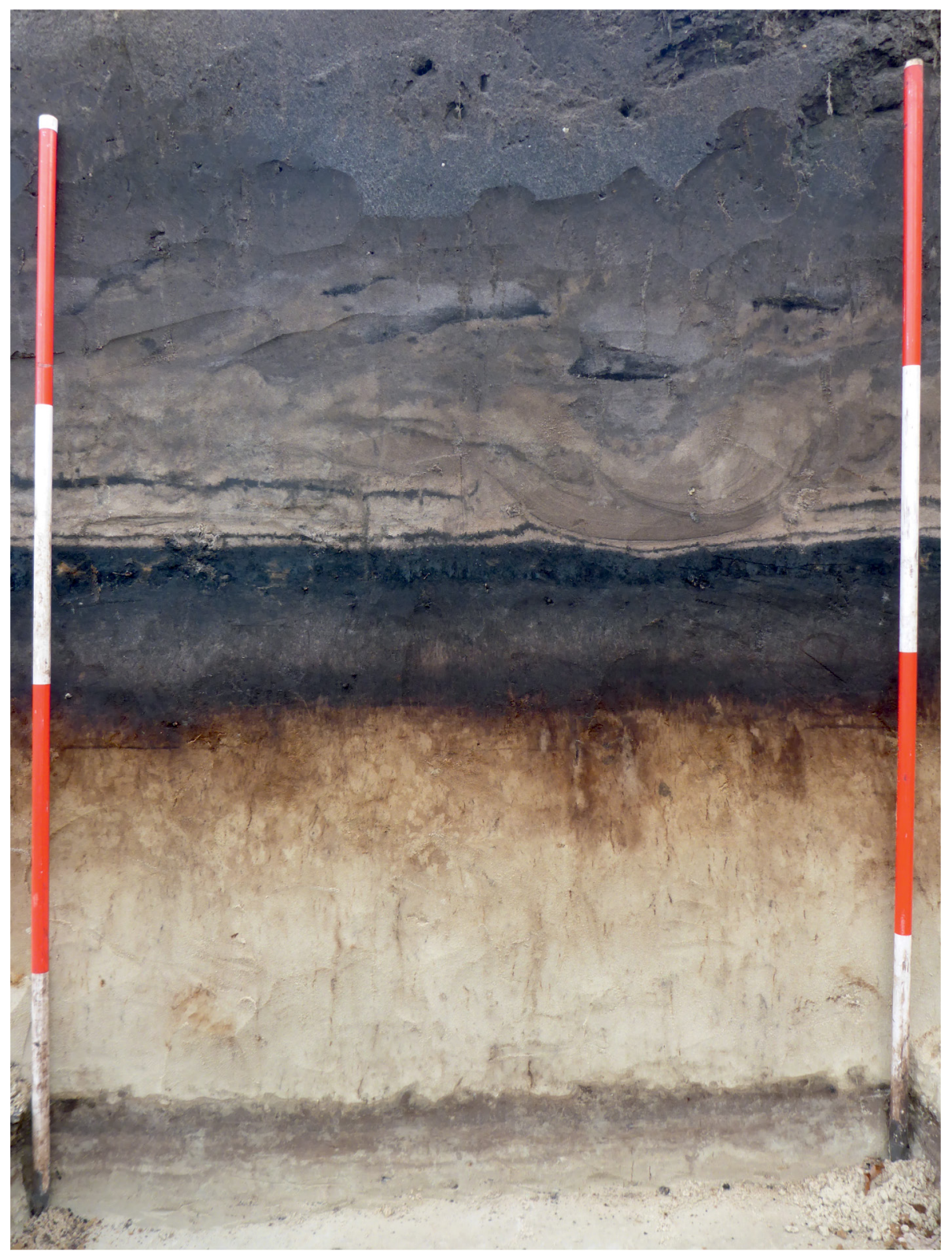

Fig. 2. Typical stratigraphic sequence at Soest-Staringlaan. At the base of the profile, the Usseloo soil horizon, separating Younger Coversand I and Younger Coversand II, is visible as a dark brown band. In the top of the coversand, a hydropodzol has formed, which is covered by later deposits (photo BAAC).

hearth pit was dated on Pinus charcoal to $8010 \pm 40$ BP (Poz-60386; 7081-6813 cal.yr. BCE), and can be placed in the middle Mesolithic period (Stolk et al. 2015). In and near the hearth pit, worked flint was present, and in the pit, larger chunks of charcoal could be seen with the naked eye. The original podzol Ah-, E- and Bhs-horizons were intact above the blueish black, charcoal-rich filling of the pit (see Fig. 3). This observation - and similar observations on a hearth pit profile at Kampen (Huisman et al. 2019) - indicate that podzol formation was still going on after the pit had been dug and filled in again. Hearth pit HAK-019 was $77 \mathrm{~cm}$ wide and at least $40 \mathrm{~cm}$ deep if we take the top of the Ah-horizon as a reference level for the original ground surface. On top of the podzol soil above the hearth pit, a thin layer of undisturbed 14th century AD aeolian sand was present (Stolk et al. 2015; Tebbens 2019). This layer has preserved the original podzol profile very well.

\section{Materials and methods}

Micromorphological samples were taken to encompass variability related to the pit itself, to lateral variation, and to the soil horizons in the profile (see Fig. 4 for sample position). Table 1 provides a base identification of the features, whereas Table 2 gives an overview description of the samples.

The samples were oven-dried and subsequently impregnated with polyester resin. The resin was hardened by using a gamma-ray treatment. A slice of each sample was mounted on a glass slide and ground, lapped and polished to a thickness of 25-30 micron, and then covered with a cover slip to produce $75 \times 110 \mathrm{~mm}$ thin sections. The thin sections were scanned with a flat-bed slide scanner and subsequently studied with a Zeiss Axioskop 40 polarization microscope with magnifications from 25 to $1000 \times$ and a mounted Zeiss MRc5 digital camera. 
Fig. 3. A: Hearth pit HAKo19/feature 246 in profile. B: The same feature in plan view (photos BAAC).
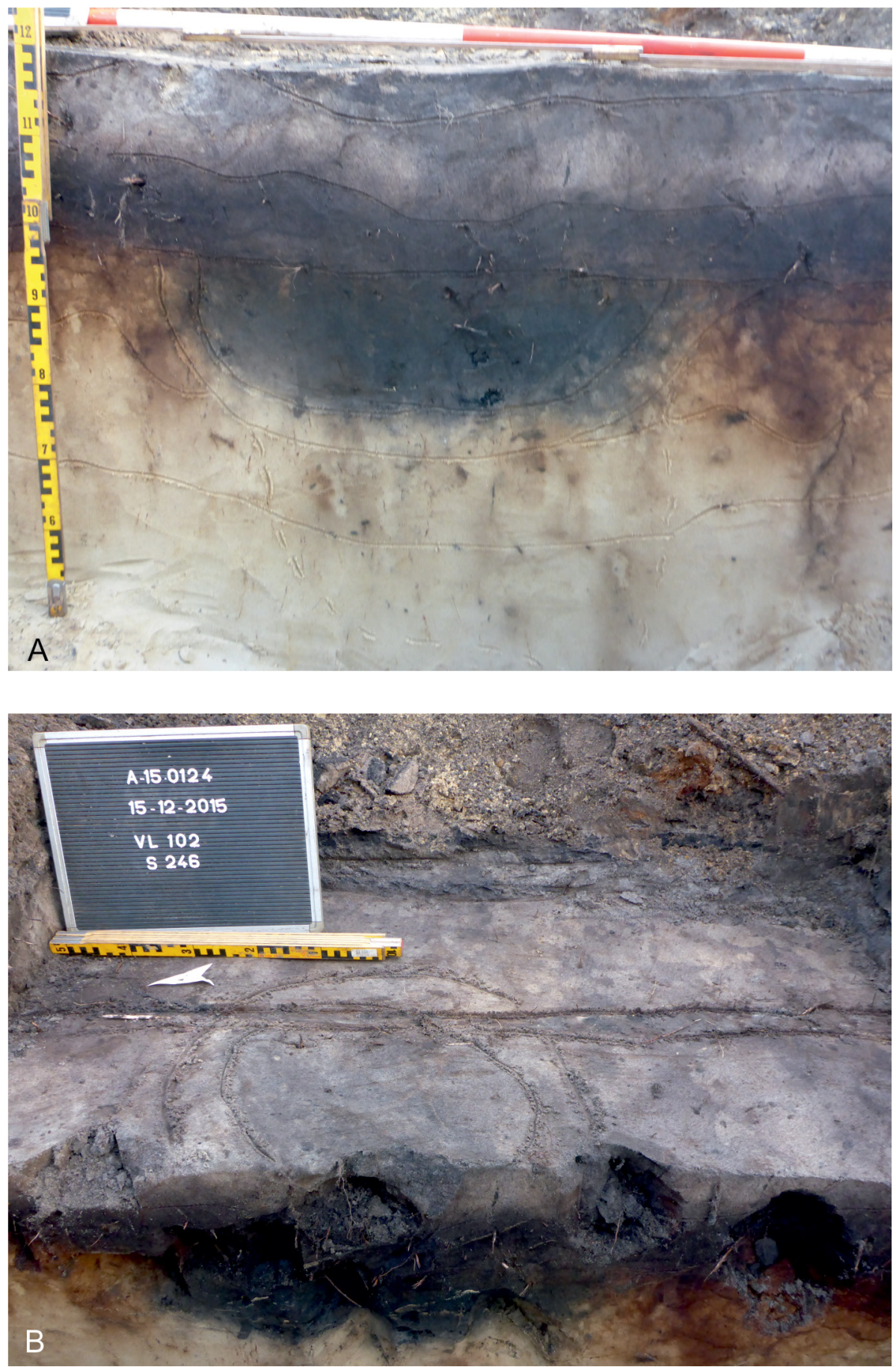

Micromorphological study focused on the various types of non-charred and charred organic materials. The plant remains were identified as roots or plant tissue, fungal hyphae, sclerotia and other types of fungal tissue (cf. Babel 1975; Bullock et al. 1985; Ismail-Meyer 2017). Degraded organic matter was classified as mesofauna excrement (mostly probably mite droppings; Babel 1975), polymorphic humus, or monomorphic humus coatings (Wilson \& Righi 2010). Charcoal, fragmented charcoal and other charred materials were described following Mallol et al. (2017) and Canti (2017). For the micromorphological characteristics of charred material types not identified in these publications (wood tar, charred monomorphic humus coatings), we refer to Huisman et al. (2019).

\section{Results}

\section{General properties}

All samples have a groundmass that consists of moderately sorted fine sand and silt, sometimes with some embedded larger sand grains. Boundaries between soil horizons and the pit proper can be recognized macroscopically in most samples that straddle such 
Table 1. Base identification of the features in the sampled profile.. Legend lithology: Zs1 = slightly silty sand, $\mathrm{H1}=$ slightly humic, $\mathrm{H2}=$ medium humic, $\mathrm{H}_{3}=$ strongly humic, Ophk1 = low charcoal content, Ophk2 = medium charcoal content.

\begin{tabular}{l|l|l|l|l}
\hline Feature & $\begin{array}{l}\text { Colour } \\
\text { (Munsell) }\end{array}$ & Lithology & Properties & Field interpretation \\
\hline 202 & 10 YR 4/4 & zs1 + zs1, H1 & Laminated & Cart track with aeolian fill? \\
\hline $246-1$ & 10 YR 2/1 & $\begin{array}{l}\text { zs1, H2, ophk2 } \\
\text { (large lumps) }\end{array}$ & $\begin{array}{l}\text { Homogeneous, rooted, } \\
\text { (beetle?) bioturbation }\end{array}$ & Upper pit fill \\
\hline $246-2$ & 10 YR 3/3 & zs1 & Mottled & Bs horizon with illuviated charcoal from 246-1 \\
\hline $246-3$ B/C & 10 YR 5/4 & zs1 & Mottled (coarse) & B/C horizon with illuviated charcoal from 246-1 \\
\hline $246-3$ C & 10 YR 6/4 & zs1 & Homogeneous & C horizon with illuviated charcoal from 246-1 \\
\hline 302 & 10 YR $2 / 1$ & zs1, H2 & No visible charcoal & Ahb horizon \\
\hline 402 & 10 YR 4/1 & zs1, (H1), ophk1 & Homogeneous & Eb horizon \\
\hline 501 & 5YR 2,5/1 & zs1, H3 & Homogeneous, with roots & Bhsb horizon \\
\hline 502 & 5 YR 3/3 & zs1, H1 & $\begin{array}{l}\text { Many humus fibres (2mm), } \\
\text { mottled, few roots }\end{array}$ & Bs horizon \\
\hline 600 & 10YR 5/6 & zs1 & Few roots (non-recent) & BC horizon \\
\hline 700 & 10 YR 6/4 & zs1 & $\begin{array}{l}\text { Homogeneous, non-layered, no } \\
\text { gravel }\end{array}$ & C horizon \\
\hline
\end{tabular}

Table 2. Description of the samples.

\begin{tabular}{l|l|l}
\hline Sample code & Feature & Field description \\
\hline 1786 & 501 & Bhsb horizon \\
\hline 1787 & 502,600 & Transition B/C to Bs horizon \\
\hline 1788 & 502,600 & Transition B/C to Bs horizon \\
\hline 1789 & $246-1$ & Upper pit fill \\
\hline 1790 & $246-1$ & Upper pit fill \\
\hline 1791 & $246-1,246-2$ & Upper pit fil and Bs horizon with illuviated charcoal from 246-1 \\
\hline 1792 & $246-3$ B/C & B/C horizon with illuviated charcoal from 246-1 \\
\hline 1794 & $246-3$ C & C horizon with illuviated charcoal from 246-1 \\
\hline 1795 & $246-2,246-3$ & Transition B/C to Bs horizon, both with illuviated charcoal \\
\hline 1796 & $501,246-1$ & Transition Bhsb horizon to upper pit fill \\
\hline
\end{tabular}

boundaries (Figure 5). These boundaries are commonly sharp and subhorizontal, although some evidence for bioturbation is present in sample 1793 .

Between the sand grains, various amounts of organic matter in different states of decay are present, as well as variable amounts of charred organic matter. No ashes or heated mineral grains were observed. An overview of the distribution of charred and non-charred organic material, is summarized in Table 3. Images of the various types of organic material are presented in Figure 6.

\section{Non-charred organic matter}

Recognizable organic plant material comes in the form of roots, in various states of decay. They occur in all samples. Non-root plant tissue was only observed in samples 1795 and 1796. Most samples have traces of fungi (hyphae, sclerotia and fungal tissue, including Mycorrhyza mantles sensu Babel [1975]; Fig. 6a), whereas mesofauna excrements (20-30 micron spheres in porous to dense microaggregates; Stoops 2003) were identified in only some of the samples $(1787,1791,1792$, 1793 ). Polymorphic humus and monomorphic humus coatings are quite common (Fig. 6a), but some samples $(1798,1794)$ seem to lack humus in any form. In some cases, illuviated monomorphic humus has filled pores or cavities in the charred material (Fig. 6b), attesting to ongoing podzolization after formation of the pit.

\section{Charred organic matter}

The charred material observed in the thin sections is quite variable. Apart from charcoal of coniferous wood, the charred material can be classified into several 
Table 3. Summary of micromorphological observations on charred and non-charred organic remains of the Soest-Staringlaan samples

\begin{tabular}{|c|c|c|c|c|c|c|c|c|c|c|c|}
\hline \multirow[t]{2}{*}{ Sample code } & \multirow[t]{2}{*}{ Unit } & \multirow[t]{2}{*}{ Feature } & \multirow[t]{2}{*}{ Groundmass } & \multicolumn{8}{|c|}{ Non-carbonized organic material } \\
\hline & & & & 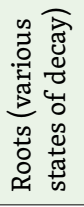 & 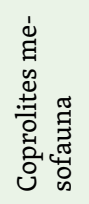 & 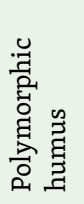 & 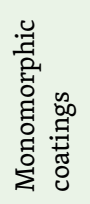 & 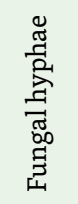 & 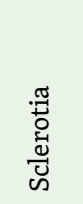 & 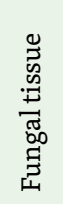 & 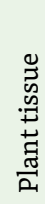 \\
\hline 1786 & Upper $1 / 2$ & 501 & & + & & $(+)$ & & & & & \\
\hline 1786 & Lower $1 / 2$ & 501 & & + & & $+(+)$ & & & & & \\
\hline 1787 & & & & + & ++ & + & $(+)$ & ++ & $+(+)$ & $++^{1}$ & \\
\hline 1788 & Left $1 / 2$ & 600 & & $(+)$ & & + & $(+)$ & ++ & & & \\
\hline 1788 & Right $1 / 2$ & 502 & & $(+)$ & & + & & + & & & \\
\hline 1789 & Upper $3 / 4$ & & & & & & & & & & \\
\hline 1789 & Lower $1 / 4$ & & Fine sand & ++ & & & + & & & & \\
\hline 1790 & & & Fine sand & + & & $+(+)$ & & ++ & & & \\
\hline 1791 & & & Fine sand & + & + & $++^{1}$ & $(+)^{2}$ & $+(+)$ & & $(+)$ & \\
\hline \multirow[t]{2}{*}{1792} & Upper $1 / 4$ & & Fine sand & + & + & & $(+)$ & $(+)$ & & & \\
\hline & Lower $3 / 4$ & & Fine sand & + & + & & $(+)$ & $(+)$ & & & \\
\hline 1793 & & & Fine sand & + & + & +1 & $(+)$ & $+(+)$ & & $(+)$ & \\
\hline 1794 & Upper $3 / 4$ & & Fine sand & $(+)$ & & & & $++^{1}$ & $++^{1}$ & & \\
\hline 1794 & Lower $1 / 4$ & & & $(+)$ & & & & $(+)$ & & + & \\
\hline 1795 & & & & + & & ++ & $(+)^{1}$ & $+(+)$ & & & + \\
\hline 1796 & & 502 & & + & & + & $+(+)^{1}$ & + & $+(+)^{2}$ & & + \\
\hline
\end{tabular}

\begin{tabular}{|c|c|c|c|c|c|c|}
\hline \multirow[t]{2}{*}{ Sample code } & \multicolumn{5}{|c|}{ Carbonized remains } & \multirow[t]{2}{*}{ Remarks } \\
\hline & 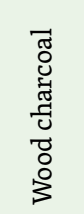 & 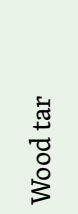 & 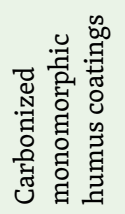 & 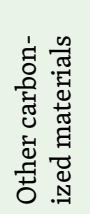 & 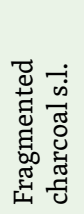 & \\
\hline 1786 & $(+)$ & & & & + & \\
\hline \multicolumn{7}{|l|}{1786} \\
\hline 1787 & & & & & & Biochannel. ${ }^{1}$ mycchorizal mantles \\
\hline \multicolumn{7}{|r|}{ (1) } \\
\hline 1788 & ++ & $+(+)$ & $(+)$ & & + & \\
\hline 1789 & $(+)$ & & & & $(+)$ & \\
\hline 1789 & $++^{1}$ & + & & $(+)^{2}$ & ++ & Wavy boundary. ${ }^{1}$ pine; ${ }^{2}$ non-woody? \\
\hline 1790 & & $(+)$ & & & & \\
\hline 1791 & $++^{3}$ & + & ++ & $++^{1}$ & ++ & ${ }^{1}$ charred raw humus; ${ }^{2}$ also precipitated on charcoal; ${ }^{3}$ pine \\
\hline \multirow[t]{2}{*}{1792} & $++^{1}$ & & & $+^{2}$ & $(+)$ & $\begin{array}{l}{ }^{1} \text { including pine wood; some brown, some black; }{ }^{2} \text { herbivorous } \\
\text { excrement }\end{array}$ \\
\hline & $(+)$ & & & & & \\
\hline 1793 & & & & & + & $\begin{array}{l}{ }^{1} \text { domains of fused plasma-like humus with embedded charred } \\
\text { fragments and some unidentified globular non-charred objects; } \\
\text { also excrements mesofauna }\end{array}$ \\
\hline 1794 & $+(+)^{1}$ & $++^{1}$ & $+(+)$ & & ++ & $\begin{array}{l}\text { Worm tunnels. }{ }^{1} \text { association of wood charcoal, tar and fungal } \\
\text { remains }\end{array}$ \\
\hline 1794 & $(+)$ & & + & & $+(+)$ & \\
\hline 1795 & & & & & $(+)$ & ${ }^{1}$ in the lower part of the sample \\
\hline 1796 & $(+)$ & $++^{3}$ & & & + & $\begin{array}{l}{ }^{1} \text { increasing in thickness with depth; }{ }^{2} \text { especially in top sample; } \\
{ }^{3} \text { one large }(\mathrm{cm}) \text { fragment }\end{array}$ \\
\hline
\end{tabular}




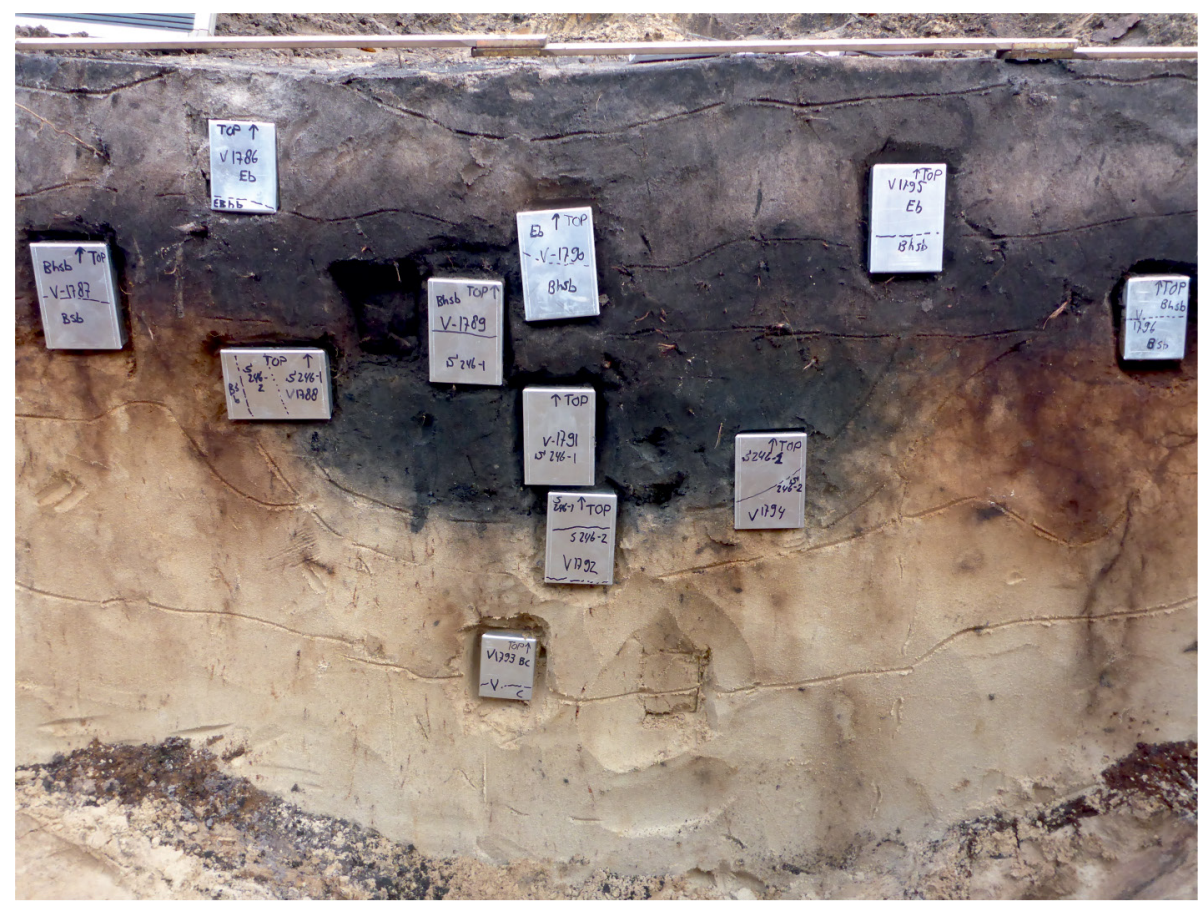

$\mathrm{N}$

MP 53

MP 54

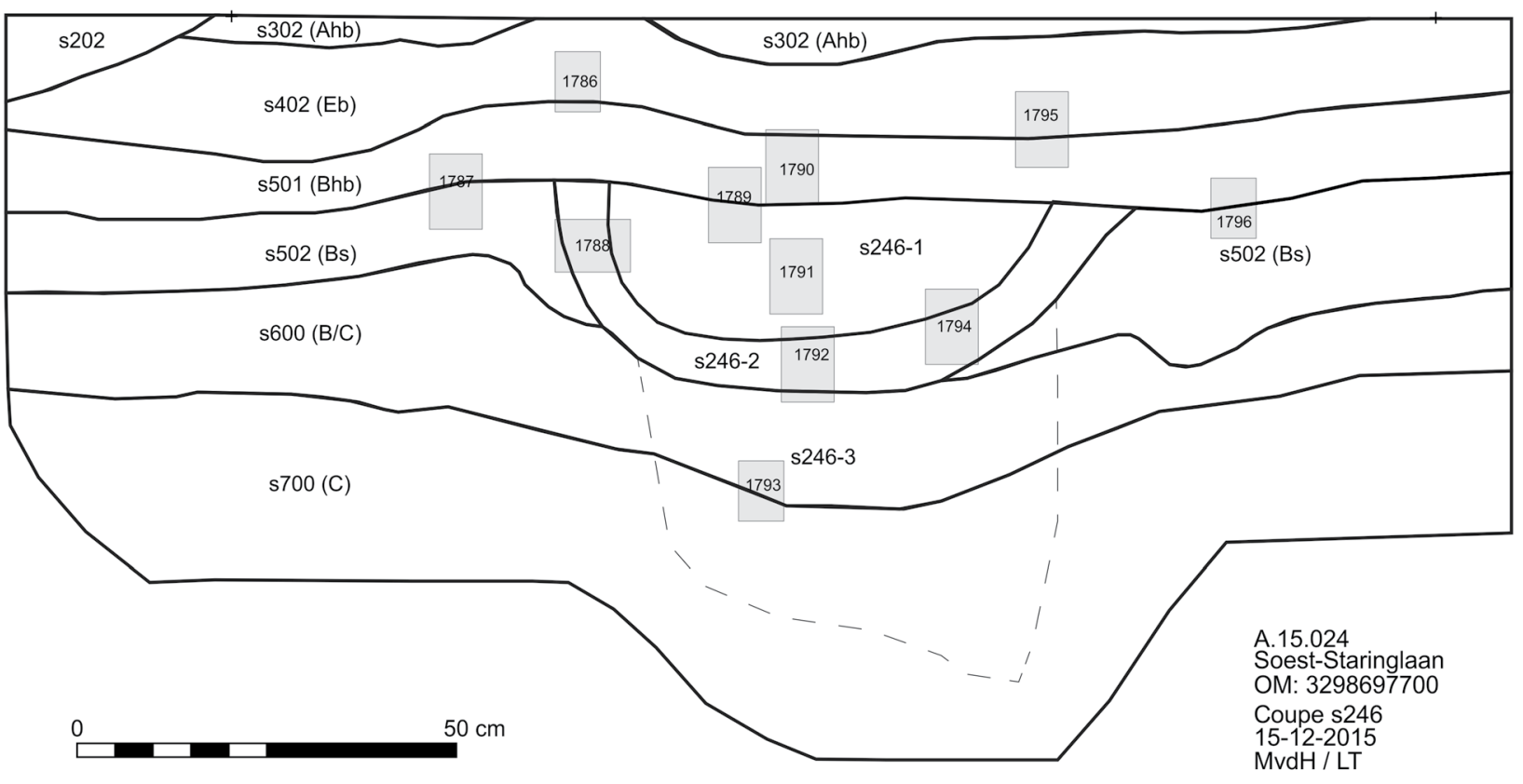

Fig. 4. A (upper): Field photograph showing the micromorphology samples in situ in the profile (photo BAAC). B (below): Drawing showing sample positions and layer/feature identification (drawing RCE).

groups. Using the terminology of Huisman et al. (2019), they include charred monomorphic humus coatings (Fig. 6c), charred polymorphic humus, charred nonwoody plant material and wood tar (Fig. 6d, e), and even what seems to be a charred excrement consisting of plant tissue (Fig. 6f). This fragment may derive from a coprolite, although it is smaller than the mouse droppings in Brönniman et al. (2017). However, several non-charred elongated coprolites of similar size and composition have been described in Huisman (2019) in samples from late prehistoric burial mounds and attributed to small, plant-eating, burrowing vertebrates. On closer inspection and considering its small size, it may be more logical to assume that this and similar coprolites originate from some sort of plant-eating invertebrate animal.

A large proportion of the charred remains consists of a fine, powdery charred material that cannot be 
a

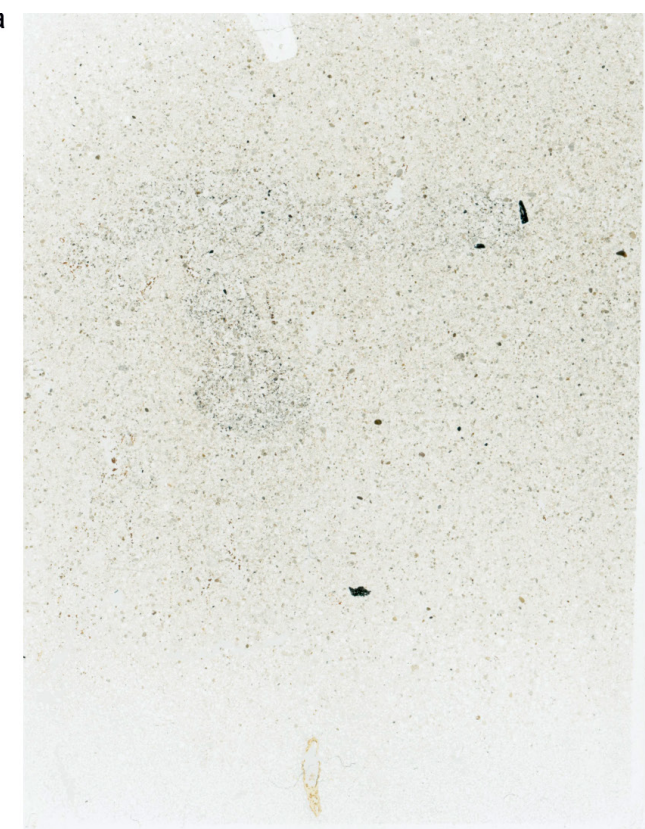

C

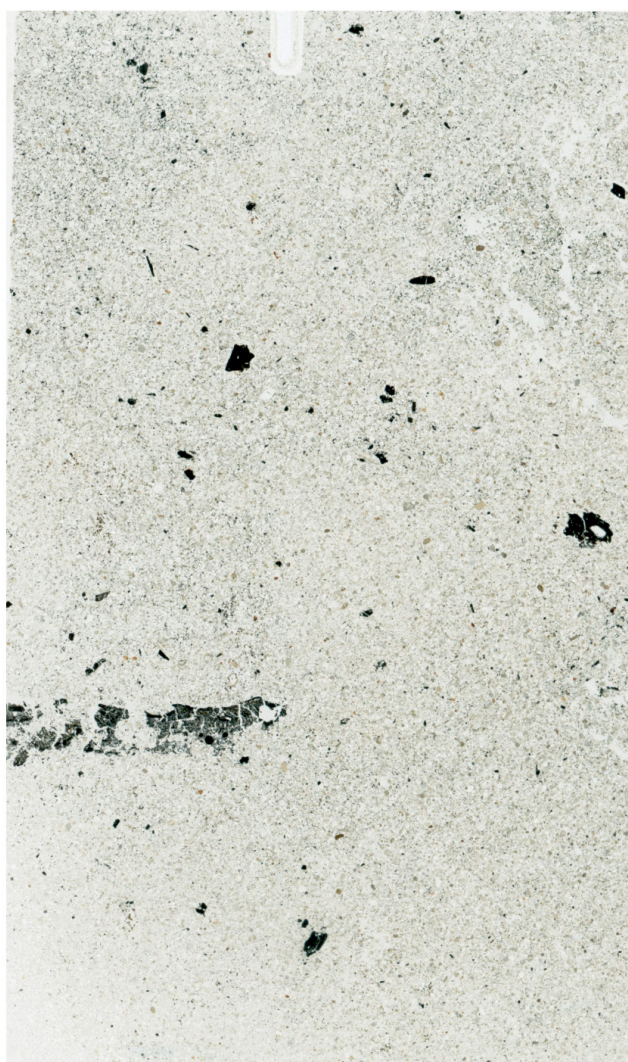

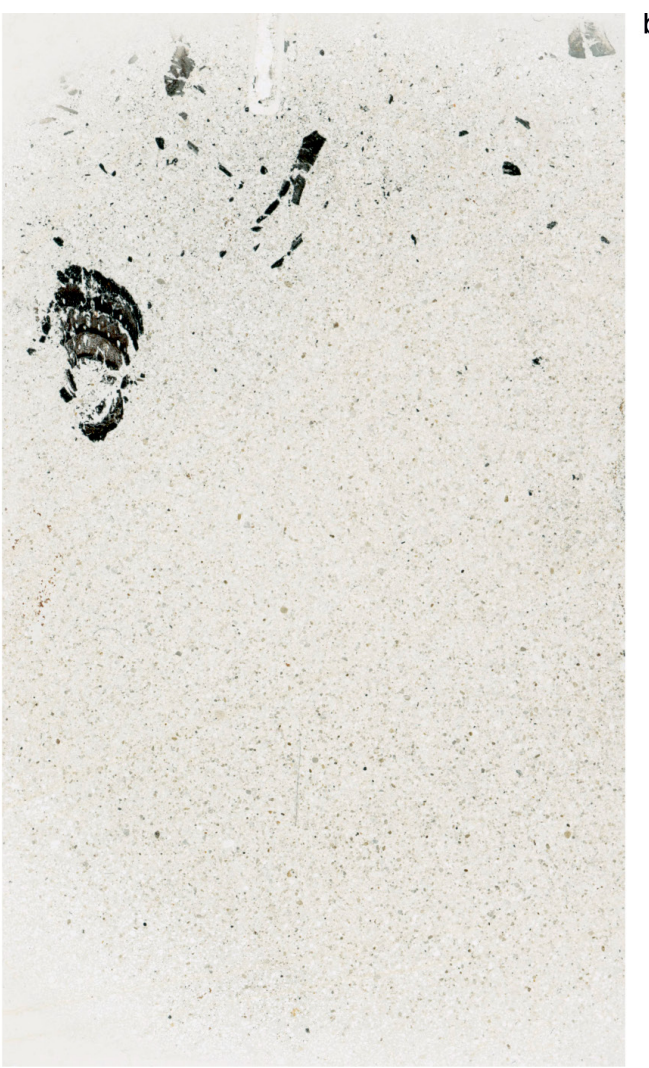

b

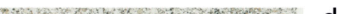

d

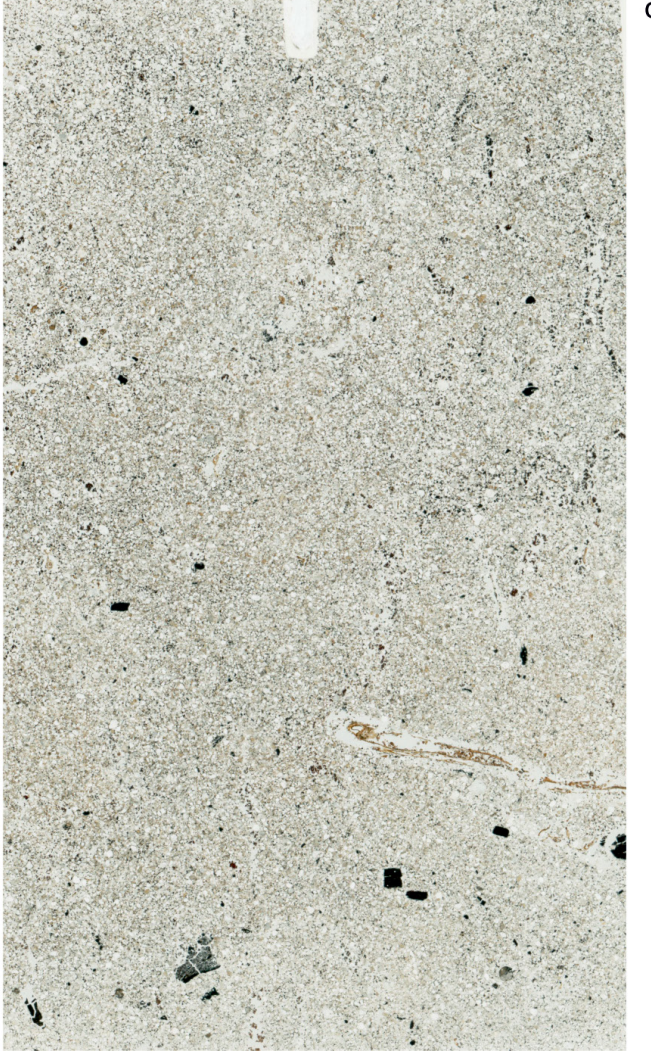

Fig. 5. Selection of scans of thin sections with feature or horizon boundaries, sequenced from bottom to top. A: Transition from C-horizon (S70o; bottom) to B/C-horizon (S60o; top) underneath the pit; sample 1793. Note the biochannel with darker infill in the centre of the image. B: Transition from B/C-horizon (S600; bottom) to the pit proper (S264-1, 2; top); sample 1 792. Note the large fragments of charcoal in the upper part of the sample. C: Transition from Bs-horizon (S502) to the pit proper (S264-1, 2; top) to the side of the pit; sample 1794. Note the large fragments of charcoal and especially the elongated, horizontal fragment in the lower left of the sample. D: Transition of pit fill (S246-1; bottom) to Bhb-horizon (S501; top); sample 1 789. The charcoal fragments are larger in the lower part of the sample, but smaller fragments are still present in the top part. 

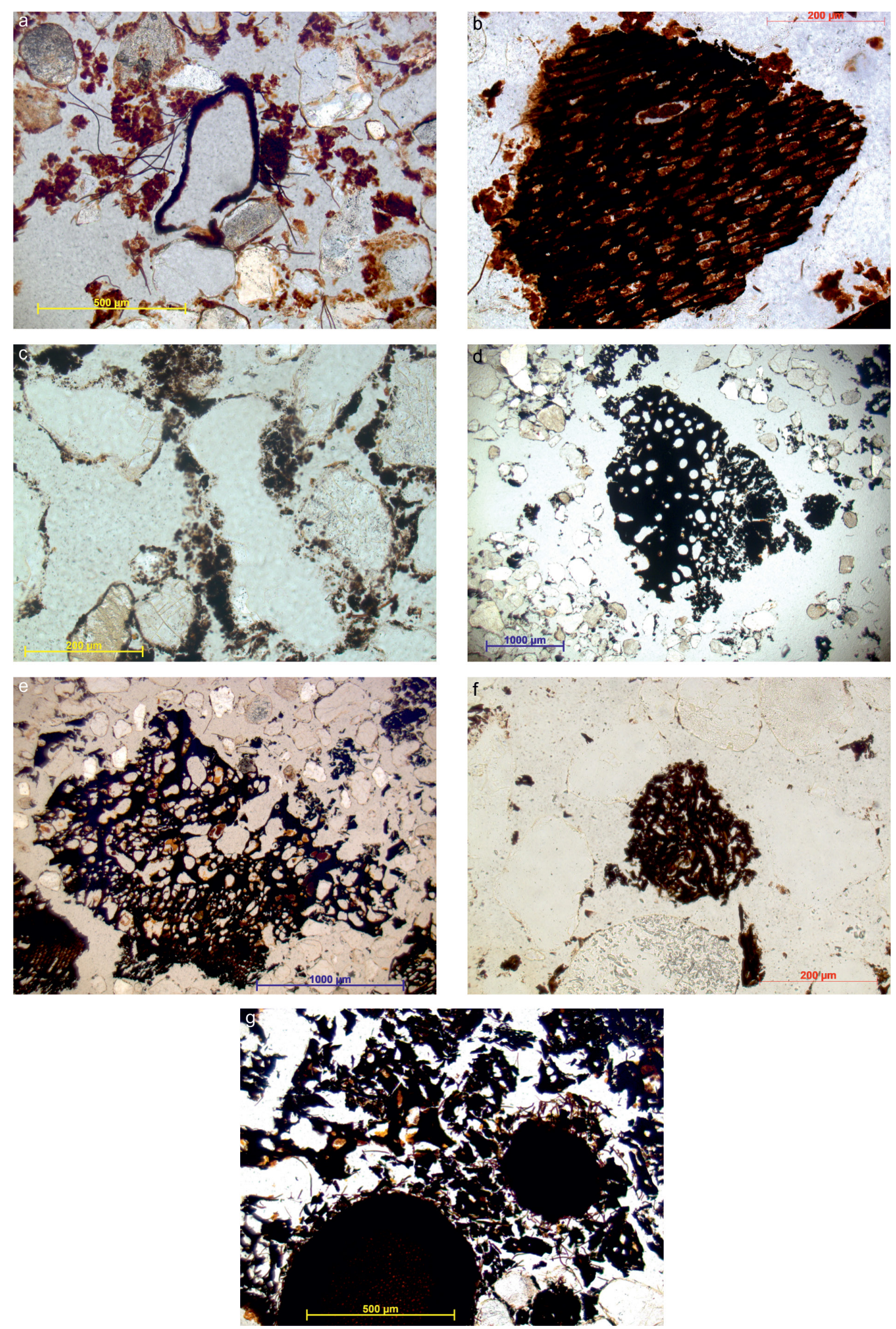

Fig. 6. Overview of different types of charred and non-charred organic remains observed in thin sections from Soest. A: Large fungal fruiting body or mycorrhizal mantle with hyphae between mineral grains. Note the polymorphic humus in between the grains and the monomorphic humus coatings on the grain at bottom right. Sample 1 781. B: Fragment of charcoal, with illuviated monomorphic humus infilling the pores and cavities. Sample 1796. C: Charred monomorphic humus coatings on sand grain. Sample 1791. D: Fragment of vesicular tar. Sample 1791. E: Wood tar with some original pore shapes preserved. Note monomorphic humus filling some of the cavities. Sample 1794. F: Clustered charred organic tissue fragments, probably charred coprolite of rodent or invertebrate. Sample 1792. G: Two large sclerotia with hyphae, surrounded by broken fragments of vesicular tar. Sample 1794. 
Polymorphic organic matter,

raw humus, mesofauna coprolites

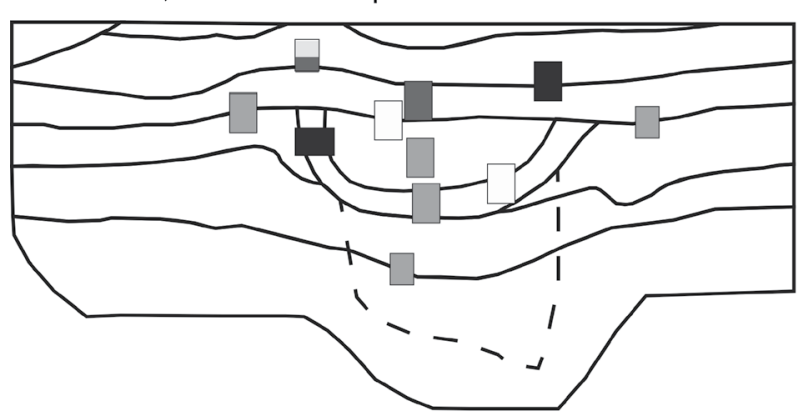

Fungal hyphae, sclerotia and

other fungal tissue

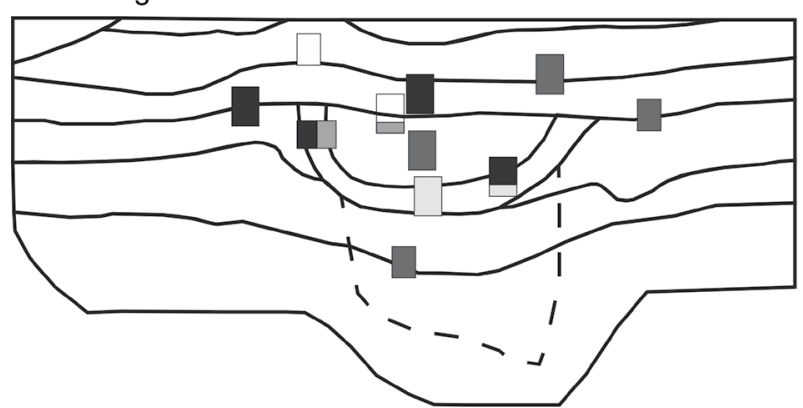

Fragmented charcoal s.l.

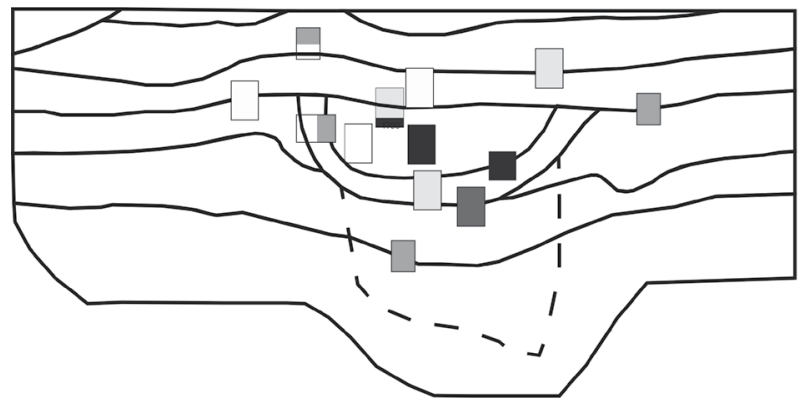

Charred humus coatings

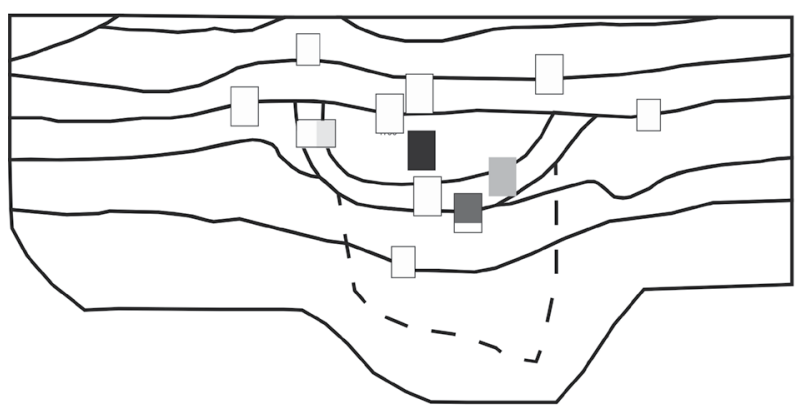

Humus coatings

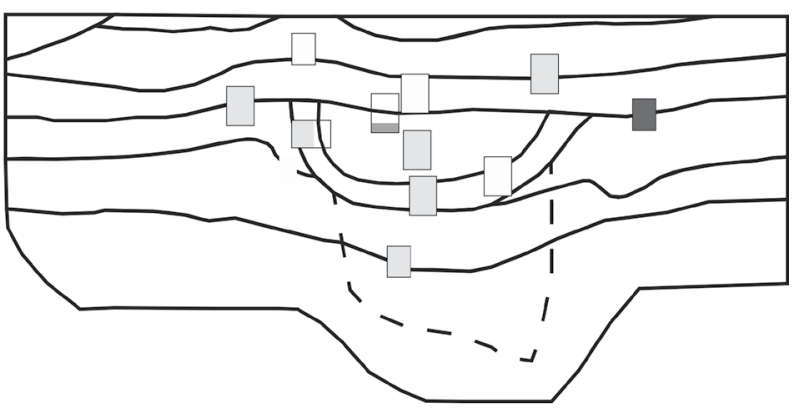

Plant tissue (non-root)

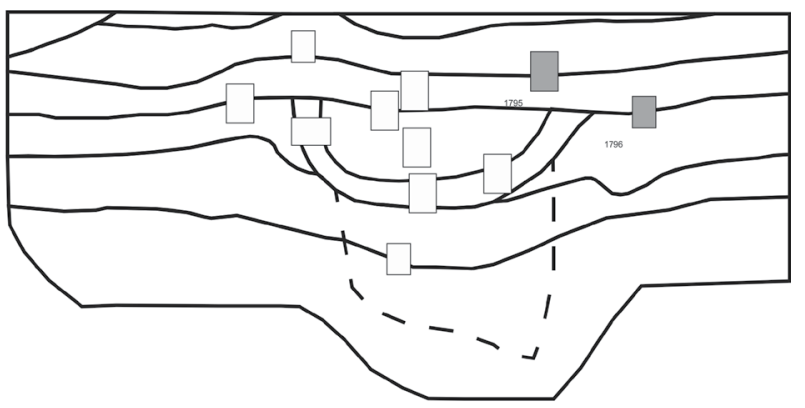

Wood charcoal

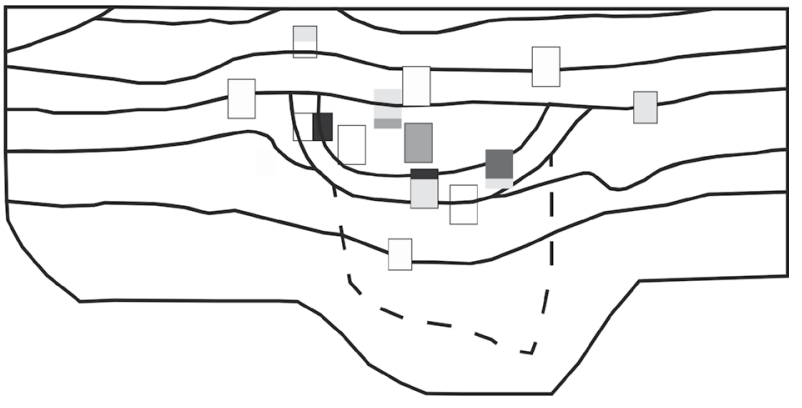

Wood tar

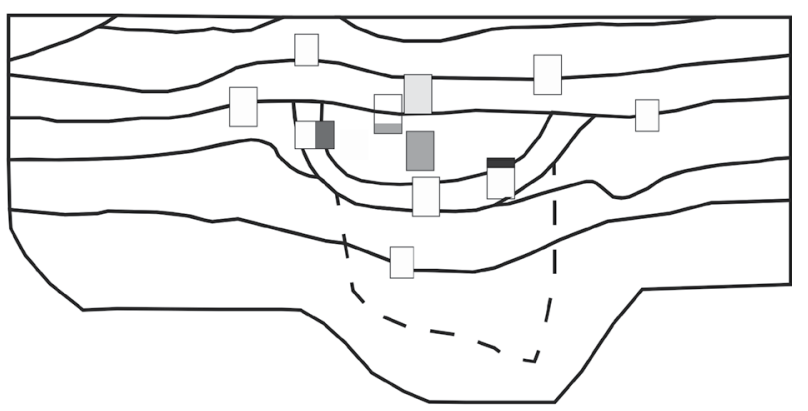

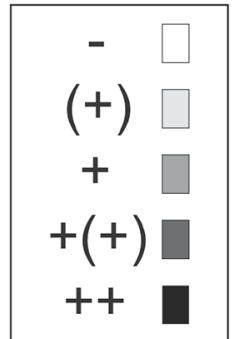

Fig. 7. Spatial properties of the presence and relative amounts of the various types of charred and non-charred organic materials that have been observed in thin sections in Soest. 
assigned to any of this class and is therefore labelled as 'fragmented charcoal s.l.' It is noteworthy that several of the samples that were taken outside of the pit feature proper, and that therefore would represent natural background values, do contain charred material: fragmented charcoal s.l. and wood charcoal can be found in samples 1788,1792 and 1796 , whereas sample 1788 also contains monomorphic humus coatings and wood tar.

The powdery 'fragmented charcoal s.l.' can be seen in most of the samples, even below the pit feature proper, and is the most common charred material. Although not completely absent in other samples, the larger amounts of wood charcoal, charred monomorphic humus coatings and wood tar are mostly present in the lower pit fill (samples 1 789, 1 791, 1794). This also corresponds with field observations of concentrations of larger, macroscopically visible charcoal fragments in the lower parts of several hearth pits and other contexts at Soest.

A remarkable observation in sample 1794 is that massive amounts of fungal tissue (including hyphae and fruiting bodies) are present in cavities and pores of a large piece of partially fragmented tar (Fig. 6e). No other clear associations between wood tar and fungi were observed.

\section{Discussion}

\section{General properties}

For the discussion, the spatial distribution of the various charred and non-charred organic matter is visualized in Figure 7.

The observations of types of non-charred and charred organic matter are in line with the observations on thin sections from other sites as reported by Kamstra (2019): The non-charred organic matter types are quite typical for the podzols that occur in these poor sandy soils. And in the Mesolithic pits, charcoal from pine is the most frequently occurring wood species - although oak and several other species occur as well. Kooistra (2019) and Huisman et al. (2020) indicate that the dominance of pine charcoal in times when deciduous trees, such as oaks and lime, were already omnipresent in the vegetation suggests a preference for the use of pine wood in these pits. The presence of tar has been observed many times - both macroscopically and microscopically, in micromorphological thin sections (Huisman et al. 2019; Kamstra 2019) and in SEM images (Kubiak-Martens et al. 2019, 644-9). Tar is easily recognized by its foam-like air bubbles and fluidization features. Charred monomorphic humus coatings - first described by Bisdom, in Spek et al. (1999, 2001) - have been observed at most sites as well (Huisman 2019; Kamstra 2019). A special observation is the presence of what is probably a charred coprolite fragment in sample 1793. Because similar but non-charred coprolites are known from archaeological soil features in sandy soils (Huisman
2019), this supports the theory put forward by Huisman et al. (2019) that at least part of the fill of Mesolithic hearth pits contains soil material that has been heated. Compared with other published sites, however, the relatively high amount of fragmented charcoal at Soest is noteworthy.

\section{Taphonomic considerations}

The presence of charred monomorphic humus coatings indicates that podzols were already present on the site when the pits were dug, and that heated and charred soil material from podzol B-horizons ended up in these pits. Huisman et al. (2019) suggest that soil material was used as a means to control specific fire properties. After the pit was filled in, podzolization continued, as attested by the infill of monomorphic organic matter in, for example, charcoal and tar fragments in Figures $6 \mathrm{~B}$ and $\mathrm{E}$. However, little accumulation of monomorphic organic matter is observed on the grains that have charred monomorphic humus coatings.

The material labelled as fragmented charcoal - also sometimes referred to as 'charcoal powder' may have different origins. Possible pathways for its formation and distribution include:

- Fragmentation of wood charcoal due to mechanical pressure - for example, trampling by humans or compression by tree or plant roots.

- Compression of charred polymorphic humus and/ or monomorphic humus coatings due to mechanical pressure - for example, trampling by humans or compression by tree or plant roots, destroying the recognizable optical features (cf. Rentzel et al. 2017).

- Disintegration of (wood) charcoal due to ash-induced alkalinity (see Slager \& van de Wetering 1977 for ash-derived alkalinity and Huisman et al. 2012 for effects on charcoal and clay movement).

- Eluviation of fine charred material (especially disintegrated charcoal) due to ash-induced alkalinity and illuviation and accumulation at greater depths in the profile. This illuviation can often be recognized as a greyish halo beneath hearth pit features, and has been observed at Soest as well as at Kampen (Huisman et al. 2019).

The considerable presence of fragmented, very finegrained charcoal in the samples taken below the pit feature (especially in sample 1793), when contrasted with the absence of other types of charred materials, is a clear indication that eluviation and illuviation played an important role in this case. The high proportion of fragmented charcoal in the other samples may indicate that rooting and maybe other types of biological activity have had a greater effect here than at the other sites that were investigated (Hoge Vaart, Dronten, Kampen). There is some logic in this, as these other sites were submerged in prehistoric times, and therefore would have 
been outside the range of (tree) roots for thousands of years. Moreover, in water-saturated soils, the processes of eluviation and illuviation are no longer active. In Soest, however, rooting has continued until modern times. Podzol formation with eluviation and illuviation processes (for which a net downwards movement of percolating water surplus in the soil profile is needed) could have continued until 5465-5225 cal. yr. BCE (the start of peat formation; see above). After that period, many parts of the site became waterlogged.

\section{Variability}

It is surprising that several of the samples that were taken as natural background samples outside the pit feature were found to contain charred material. In one sample underneath the pit feature (1793) this presence concerns only fragmented charcoal, which can be linked to eluviation and illuviation processes. However, this is not the case for the wood charcoal in sample 1792 (immediately below the pit) and the wood charcoal and fragmented charcoal in sample 1796 (next to the pit), nor for the combination of wood charcoal, charred humus coatings and wood tar in sample 1788 on the edge of the feature. These samples may indicate that the Mesolithic hearth pit was originally wider and deeper than was observed in profile. It is possible that additional fills of the pit were, in fact, present, but that the outer fills were not recognizable in the field. Another option is that tree roots caused displacement of soil material - although in our opinion this is less likely because the pattern seems to be too systematic for this. Finally, as can be seen in Figure 2, the profile does not intersect with the centre of the pit. As a result, some of the samples may just have contained material from a different feature, not visible in the profile. However, the samples are relatively shallow $(2 \mathrm{~cm})$, so this effect is unlikely to have had a large impact. It does seem, therefore, that only sample 1787 represents a true background of the natural soil profile, whereas samples 1788 and 1796 form part of the anthropogenic feature.

Within the pit, it is clear that there is a large macroscopic and microscopic difference between the upper and the lower fill. For the present, we assume that the charred material in the lower fill is a direct reflection of anthropogenic activities. We further assume that the charred material in the upper fill - which probably represents backfilling of the pit (see Huisman et al. 2020) may represent more general anthropogenic refuse, not necessarily linked to the activities performed in or with the pit itself. Even taking this into account, it is clear that there are considerable differences between the samples within a single pit fill.

This study leads to two recommendations for future research on Mesolithic pit hearths. This study confirms the value of investigating these phenomena in soil profiles. Especially the properties of the upper pit fills are underrepresented in the available dataset. Therefore, we recommend that future excavations use excavation strategies that increase the chances of encountering these pits in profile. The high morphological variability of charred and non-charred organic remains puts restraints on the interpretability of small numbers of samples, especially when of smaller sizes. Therefore, we recommend that future excavations take multiple samples, and that they take variability into consideration in all hearth pit-related research.

We note that, although numerous research efforts have targeted Mesolithic hearth pits - including their micromorphology - and although much more is understood about their formation and taphonomic processes, the evidence pointing to a specific use of these pits is still not conclusive. However, a growing body of evidence - including from Fourier transform infrared spectroscopy (FTIR) analysis, from charcoal temperature research and from the occurrence of wood tar in polished slides in this research - suggests the production of wood tar (used for hafting stone artefacts or to make leather more waterproof) as one of the most likely processes (Kooistra 2019; Kubiak-Martens et al. 2019). However, we still cannot exclude that these features are a by-product of another use that required oxygen-starved fires. It may be necessary to turn to other techniques, including additional chemical approaches, and to experimental work, to advance this research (e.g. Kubiak-Martens et al. 2019).

\section{Conclusions}

This micromorphological research has first and foremost demonstrated the strong variability between samples within the same Mesolithic hearth pit feature. This implies that multiple samples from a pit are necessary in order to at least attempt to try to capture this variability. It is also clear from the results that sampling should include layers or deposits that, macroscopically, seem to be outside the feature proper: These may contain parts of the phenomenon studied that are difficult to recognize with the naked eye.

Most of the organic features in the sampled hearth pit from Soest-Staringlaan are similar to those found in other pits, at Kampen, Dronten and Hoge Vaart (Spek et al. 1999, 2001; Van Kappel \& Exaltus 2012, 2019; Huisman et al. 2019; Kamstra 2019). Common features include the presence of large fragments of charcoal in the lower parts, tar, charred humus and evidence for charcoal disintegration and eluviation. New from Soest is the presence of a charred excrement, which supports the notion that soil material has become heated, charring not only humus, but also (a fragment of) soil fauna excrement.

These observations add support to the notion that Mesolithic hearth pits are generally formed by the same human activities, formation processes and taphonomy. 
More observations are needed to test this, and supplemental chemical analyses may be needed to better understand the formation of these common Mesolithic features.

\section{Acknowledgements}

We would like to thank Jan-Willem de Kort and Menno van der Heiden (Cultural Heritage Agency of the Netherlands) for their assistance in the sampling fieldwork and for providing a previous version of Figure 4B.

\section{References}

ACHARD-COROMPT, N., E. GHESQUIÈRE, C. LAURELUT, A. REMY, R. ISABELLE, V. RIQUIER \& L. SANSON, 2017. Des fosses par centaines, une nouvelle vision du Mésolithique en Champagne: analyse et cartographie d'un phénomène insoupçonné. In: N. Achard-Corompt, E. Ghesquière \& V. Riquier (eds.), Creuser au Mésolithique - Digging in the Mesolithic, actes de la séance de la Société préhistorique française (Châlonsen-Champagne, 29-30 mars 2016), Séances de la Société préhistorique française, vol. 12, Société Préhistorique Française, Paris, 11-25.

BLINKHORN, E., E. LAWTON -MATTHEWS. \& G. WARREN, 2017. Digging and filling pits in the Mesolithic of England and Ireland: comparative perspectives on a widespread practice. In: N. Achard-Corompt, E. Ghesquière \& V. Riquier (eds.), Creuser au Mésolithique - Digging in the Mesolithic, actes de la séance de la Société préhistorique française (Châlonsen-Champagne, 29-30 mars 2016), Séances de la Société préhistorique française, vol. 12, Société Préhistorique Française, Paris, 211-224.

BRÖNNIMAN, D., CH. PÜMPIN, K. ISHMAIL-MEYER, PH. RENTZEL \& N. ÉGÜEZ, 2017, Excrements of omnivores and carnivores. In: C. Nicosia, \& G Stoops (eds.), Archaeological Soil and Sediment Micromorphology: Chichester, Wiley Blackwell, 67-82.

BOYD, W.E. \& J.B. KENWORTHY, 1991. The use of wood as a natural resource at a Scottish Mesolithic site. Glasgow Archaeological Journal, 17, 11-24.

BABEL, U., 1975. Micromorphology of soil organic matter. In: J.E. Giesking, (ed.), Soil Components: Organic Components, Volume 1: New York, Springer-Verlag, 369-473.

BULLOCK, P., N. FEDOROFF, A. JONGERIUS, G. STOOPS, \& T.TURSINA, 1985. Handbook for Soil Thin Section Description, Wolverhampton, Waine Research Publications

CANTI, M.G., 2017. Charred plant remains. In: C. Nicosia, \& G Stoops (eds.), Archaeological Soil and Sediment Micromorphology: Chichester, Wiley Blackwell, 141-142

CROMBÉ, PH., R. LANGOHR \& G. LOUWAGIE, 2015. Mesolithic hearth-pits: fact or fantasy? A reassessment based on the evidence from the sites of Doel and Verrebroek (Belgium). Journal of Archaeological Science 61, 158-171.
CROMBÉ, PH. \& R. LANGOHR, 2020. On the origin of Mesolithic charcoal-rich pits: A comment on Huisman et al. 2019: Journal of Archaeological Science 119, 105058

DIELEMANS, L., 2018. Utrecht in de prehistorie. HFD01: Een archeologische opgraving van sporen uit de steen-, brons- en ijzertijd langs de Hoofddijk, de Uithof, Utrecht, (Basisrapportage Archeologie 112) Utrecht, Gemeente Utrecht

GROENENDIJK, H.A., 1987. Mesolithic hearth-pits in the Veenkoloniën (prov. Groningen, the Netherlands), defining a specific use of fire in the Mesolithic. Palaeohistoria 29, 85-102.

HUISMAN, D.J., F. BRAADBAART, I.M. VAN WIJK, \& B.J.H. VAN OS, 2012. Ashes to ashes, charcoal to dust: micromorphological evidence for ash-induced disintegration of charcoal in Early Neolithic (LBK) soil features in Elsloo (The Netherlands). Journal of Archaeological Science, 39, 994-1004.

HUISMAN, D.J., M.T. NIEKUS, J.H.M. PEETERS, R.C.A. GEERTS \& A. MÜLLER, 2019. Deciphering the complexity of a 'simple' Mesolithic phenomenon: Indicators for construction, use and taphonomy of pit hearths in Kampen (the Netherlands). Journal of Archaeological Science, 109, 104987.

HUISMAN, D.J., 2019. Soil Micromorphology, In: A. Louwen \& D. Fontijn, Death revisited. The excavation of three bronze age barrows and surrounding landscape at Apeldoorn-Wiesselseweg, Sidestone Press, Leiden, 52-54.

HUISMAN, D.J., M.T. NIEKUS, J.H.M. PEETERS, R.C.A. GEERTS \& A. MÜLLER, 2019. Arguments in favour of an anthropogenic origin of Mesolithic pit hearths. A reply to Crombé and Langohr (2020). Journal of Archaeological Science 119, 105144.

ISMAIL-MEYER, K., 2017. Plant remains, In: C. Nicosia, \& G Stoops (eds.), Archaeological Soil and Sediment Micromorphology: Chichester, Wiley Blackwell, 131-136.

KAMSTRA, H.K, 2019. Fire under the lens: The Mesolithic magnified. A study into the use and function of Mesolithic hearth pits in the Netherlands through the use of soil micromorphology. Research Master's Thesis - Archaeology, Groningen, Groningen Institute of Archaeology.

KOOISTRA, L., 2019. Houtskool uit mesolithische sporen. In: I. Woltinge, M. Opbroek, L.A. Tebbens, I. Devriendt \& E. Drenth, Mesolithisch verblijf en maretakspitsen aan de Staringlaan te Soest. De opgraving van een mesolithische 'persistent place' (BAAC-rapport A-15.0124), 's-Hertogenbosch, BAAC 617-640.

KUBIAK-MARTENS, L., 2002. New evidence for the use of root foods in pre-agrarian subsistence recovered from the late Mesolithic site at Halsskov, Denmark. Vegetation History and Archaeobotany 11, 23-32.

KUBIAK-MARTENS, L., J.J. LANGER, L.I. KOOISTRA \& L.A. TEBBENS, 2019. Teer en bitumen uit mesolithische sporen. In: I. Woltinge, M. Opbroek, L.A. Tebbens, I. Devriendt \& E. Drenth, Mesolithisch verblijf en maretakspitsen aan de Staringlaan te Soest. De opgraving van een mesolithische 'persistent place' (BAAC-rapport A-15.0124, deel 2), , 's-Hertogenbosch, BAAC 641-657.

MALLOL, C., S.M. MENTZER, \& C.E. MILLER, 2017. Combustion features. In: C. Nicosia, \& G Stoops (eds.), Archaeological Soil and Sediment Micromorphology: Chichester, Wiley Blackwell, 299-330. 
PEETERS, J.H.M, \& J.W.H. HOGESTIJN, 2001. Deel 20. Op de grens van land en water: jagers-vissers-verzamelaars in een verdrinkend landschap. In: J.W.H. Hogestijn \& J.H.M. Peeters, J.H.M. (eds.), De mesolithische en vroeg-neolithische vindplaats Hoge Vaart-A27 (Flevoland), Rapportage Archeologische Monumentenzorg 79, Amersfoort, ROB.

PEETERS, H. \& M. NIEKUS, 2017. Mesolithic Pit Hearths in the Northern Netherlands. Function, Time-Depth and Behavioural Context. In: N. Achard-Corompt, E. Ghesquière \& V. Riquier (eds.), Creuser au Mésolithique - Digging in the Mesolithic, actes de la séance de la Société préhistorique française (Châlonsen-Champagne, 29-30 mars 2016), Séances de la Société préhistorique française, vol. 12, Société Préhistorique Française, Paris, 225-239.

RENTZEL, P., C. NICOSIA, A. GEBHARDT, D. BRÖNNIMANN, C. PÜMPIN, \& K. ISMAIL-MEYER, 2017. Trampling, poaching and the effects of traffic. In: C. Nicosia, \& G Stoops (eds.), Archaeological Soil and Sediment Micromorphology: Chichester, Wiley Blackwell, 281-298.

SLAGER, S. \& H.T.J. VAN DE WETERING, 1977. Soil formation in archaeological pits and adjacent loess soils in Southern Germany. Journal of Archaeological Science 4, 259 - 267.

SPEK, T., E.B.A. BISDOM, \& D.G. SMEERDIJK, 1999. Verdronken dekzandgronden in Zuidelijk Flevoland (archeologische opgraving 'Hoge Vaart-A27'): een aanvullend bodemkundig en palaeocologisch onderzoek naar de landschapsvormende processen tijdens de laatste fase van de landschapsvormende processen tijdens de laatste fase van de bewoning (Vroeg-Neolithicum). (Staring Centrum Rapport 472.2 55), Wageningen, Staring Centrum.

SPEK, T., E.B.A. BISDOM, \& D.G. SMEERDIJK, 2001. Deel 8. Bodemkunde en landschapsecologie II: aanvullend onderzoek naar landschapsvormende processen. In: J.W.H. Hogestijn \& J.H.M. Peeters, J.H.M. (eds.), De mesolithische en vroeg-neolithische vindplaats Hoge Vaart-A27 (Flevoland), Rapportage Archeologische Monumentenzorg 79, Amersfoort, ROB.
STOLK, T., M.K. WIJKER \& T. D'HOLLOSY, 2015. Archeologisch onderzoek Sportveld Staringlaan, Soest, (CAR-rapport 37), Amersfoort, Centrum voor Archeologie.

STOOPS, G., 2003. Guidelines for Analysis and Description of Soil and Regolith Thin Sections. Madison, Wisconsin, Soil Science Society of America Inc.

TEBBENS, L.A., 2019. Landschapontwikkeling en bodemkundige situatie. In: I. Woltinge, M. Opbroek, L.A. Tebbens, I. Devriendt \& E. Drenth, Mesolithisch verblijf en maretakspitsen aan de Staringlaan te Soest. De opgraving van een mesolithische 'persistent place' (BAAC-rapport A-15.0124, deel 1), 's-Hertogenbosch, BAAC 93-135.

VAN KAPPEL, K. \& R. EXALTUS, 2012. Bijlage I: bodemmicromorfologisch onderzoek vindplaats 5. In: T. Hamburg, A. Müller \& B. Quadflieg, (eds.), Mesolithisch Swifterbant. Mesolithisch gebruik van een duin ten zuiden van Swifterbant (83005000 v. Chr.). Een archeologische opgraving in het tracé van de N23, ARCHOL, Leiden, 447-492.

VAN KAPPEL, K. \& R. EXALTUS, 2019. Bijlage III: Micromorfologisch onderzoek grondlagen. In: R.C.A. Geerts, A. Müller, M.J.L.Th. Niekus, \& F.J. Vermue, 2019. Mesolithische kampen onder de oever van het Reevediep. Een archeologische opgraving van vindplaats 9 in het tracé van de hoogwatergeul in het Reevediep te Kampen. ( $\mathrm{ADC}$ monografie 26), Amersfoort, $\mathrm{ADC}$, 341-349.

WILSON, M.A. \& D. RIGHI, 2010. Spodic materials. In: G. Stoops, V. Marcellino \& F. Mees, Interpretation of micromorphological features of soils and regoliths, Amsterdam, Elsevier, Amsterdam, $251-273$.

WOLTINGE, I., M. OPBROEK, L.A. TEBBENS, I. DEVRIENDT \& E. DRENTH, 2019. Mesolithisch verblijf en maretakspitsen aan de Staringlaan te Soest. De opgraving van een mesolithische 'persistent place' (BAAC-rapport A-15.0124). 's-Hertogenbosch, BAAC. 
